Link article (Style APA): Chykhantsova O. A. (2020). A person's quality of life and features of its measurement.Insight:the psychologicaldimensionsofsociety, 4,11-28.DOI: 10.32999/2663-970X/2020-4-1

Link article (Style DSTU 8302: 2015): Chykhantsova, O. A. A person's quality of life and features of its measurement. Insight: the psychological dimensions of society, 2020, 4, 11-28. DOI: 10.32999/2663970X/2020-4-1

UDC 159.923

\title{
A person's quality of life and features of its measurement
}

\section{Якість життя особистості та особливості її вимірювання}

Received: August 04, 2020

Chykhantsova Olena Anatoliivna

Ph. D. in Psychology, Associate Professor

Chamata Laboratory of Psychology of Personality

G. S. Kostiuk Institute of Psychology of the NAES of Ukraine, Ukraine chyhantsova@gmail.com, ORCID 0000-0002-2661-3265
Accepted: October 30, 2020

\author{
Чиханцова Олена Анатоліївна \\ кандидат психологічних наук, доцент \\ лабораторія психології особистості \\ імені П. Р. Чамати \\ Інститут психології імені Г.С. Костюка \\ НАПН України, Україна \\ chyhantsova@gmail.com, \\ ORCID 0000-0002-2661-3265
}

\begin{abstract}
The article conveys the results of a practical evaluation of the methods of psychodiagnostics $(n=117)$ under the framework of studying a person's quality of life by applying the author's questionnaire. The purpose of the research is to examine the value of the assessment of quality of life for its further use and specify the level of human quality of life as a psychological category. Research methods: the author's questionnaire, standardized tests, correlation analysis, descriptive statistics. Results. It is presented the author's model of quality of life which is based on the idea that the actual value of quality of life is reflected in the subjective feelings of an individual, and these feelings are developed through the prism of specific objective conditions. The article identifies the psychological features and indices which clarify the parameters of manifestation of the quality of life. It is introduced the standardization of the author's method "Person's Quality of Life Questionnaire", which consists of 16 statements, and presented the results of a practical evaluation of the method. The distribution of the levels of quality of life has the following points: a low level of quality of life - 16-56 points, an average level of quality of life - 57-58 points, a high level of quality of life $-86-112$ points. The measurement of quality
\end{abstract}

\section{Анотація}

У статті представлені результати апробації психодіагностичної методики $(\mathrm{n}=117)$ на вивчення якості життя особистості з використанням авторського опитувальника. Метою $є$ дослідження значення оцінки якості життя для подальшого його використання та визначення рівня якості життя людини як психологічної категорії. Методи дослідження: авторський опитувальник, тести зі стандартизованими анкетами, кореляційний аналіз, описові статистики. Результати. Представлено авторську модель якості життя, в основі якої $є$ твердження, що дійсне значення якості життя відображене в суб'єктивних відчуттях людини, а ці відчуття формуються на основі конкретних об'єктивних умов і визначено психологічні ознаки та показники, які конкретизують параметри прояву якості життя. Представлено стандартизацію авторської методики "Опитувальник якості життя особистості”, який містить 16 тверджень та наведено результати апробації даної методики. Розподіл рівнів якості життя має наступні бали: низький рівень якості життя - 16-56 балів, середній рівень якості життя - 57-58 балів, високий рівень якості життя - 86-112 балів. Вимірювання якості життя грунтується на оцінці людиною

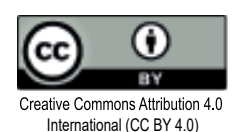


of life is grounded on a person's assessment of his or her physical, mental, social and economic well-being. The reliability of the methods of studying the person's quality of life is high $(\alpha=.802)$. The author's method is investigative and thus, doesn't estimate the degree of manifestation of the measured parameters, their standardizing. However, it allows defining the descriptive, qualitative, quantitative characteristics of the features under study. A positive interrelation between the indicators of the quality of life and hardiness $(=.736 ; \mathrm{p} \leq .01)$, satisfaction with life $(=.707 ; \mathrm{p} \leq .01)$, subjective happiness $(=.659 ; \mathrm{p} \leq .01)$ and self-efficacy $(=.629 ; \mathrm{p} \leq .05)$ is found out. Conclusions. It has been determined such constituents of a person's quality of life as subjective and objective and highlighted a particular significance of the very subjective assessment of the quality of life for the mental health of an individual.

Key words: quality of life assessment, satisfaction with life, hardiness.

\section{Introduction}

In the context of activation of the processes of population ageing and depopulation in Ukraine, a human resource becomes the most deficient that enhances the relevance of the issue of quality of life. Nowadays a high quality of life is considered to be a feature of the state's prosperity, and the experience of leading countries confirms that in the strategy of the national development, it is expedient to focus on the concept of quality of life of a person.

An interest in the problem of quality of life is growing, however, the scientific environment has a lack of a unified approach to the content of the very concept "quality of life" and its generally recognized measurement framework and procedure. The assessment of quality of life can be defined as a way of identifying a degree of conformity of the basic parameters and conditions of a person's life to his or her vital needs as well as the personal ideas of decent living standards. Moreover, the problem turns to be more social, inter-disciplinary and currently requires follow-up study.

According to Zh. Virna, quality of life can be interpreted as the level of a person's adjustment both to his or her inner world and society (Virna, 2013). Thereafter, quality of life is a multi-faceted concept and thus, scientists are fixed not on its overall index of quality of life but its components: рівня свого добробуту в фізичному, психічному, соціальному і економічному відношеннях. Надійність методики вивчення якості життя особистості $\epsilon$ високою ( $\alpha=.802)$. Авторська методика $є$ дослідницькою, тому не визначає ступінь вираженості діагностованих параметрів, їх нормування, хоча дозволяє визначити змістові, якісні, кількісні характеристики досліджуваних якостей. Виявлено позитивний взаємозв'язок між показниками якості життя та життєстійкістю(=.736; р $\leq .01)$, задоволеністю життям(=.707; р $\leq .01)$, суб'єктивним щастям (=.659; p $\leq .01)$ і самоефективністю (=.629; p $\leq .05)$. Висновки. Визначено складові якості життя особистості такі як суб'єктивна та об'єктивна і підкреслено особливу значимість саме суб'єктивної оцінки якості життя для психічного здоров'я людини.

Ключові слова: оцінка якості життя, задоволеність життям, життєстійкість.

\section{Вступ}

В Україні в умовах активізації процесів старіння й депопуляції населення людський ресурс стає найдефіцитнішим, а це збільшує значущість проблеми якості життя. У сучасному світі висока якість життя населення вважається ознакою благополуччя держави, а досвід провідних країн свідчить, що в стратегії розвитку держави доцільно орієнтуватися на концепцію якості життя людини.

Інтерес до проблеми якості життя зростає, проте в науковому середовищі ще не сформувався єдиний підхід до змісту самого поняття “якість життя", немає загальновизнаної методології і методики його вимірювання. Оцінку якості життя можна визначити як спосіб виявлення ступеня відповідності основних параметрів і умов життєдіяльності людини ії життєвим потребам, а також власним уявленням про достойне життя. Окрім того, проблема дедалі більше стає соціальною, міждисциплінарною і на сьогодні потребує додаткового вивчення.

На думку Ж. Вірної, якість життя можна визначити як рівень пристосованості людини до свого внутрішнього світу, так і до суспільства (Вірна, 2013). Таким чином, якість життя це поняття багатофакторне, тому дослідники зацікавлені не у загальному показнику якості життя, а у його компонентах: задоволеність 
A person's quality of life and features of its measurement

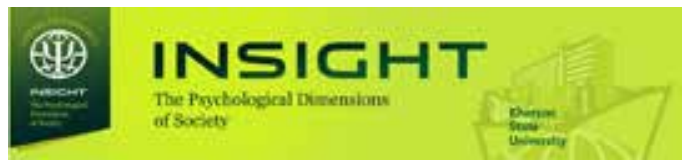

ступенем фізичного (активність, рухомість, можливість самообслуговування), психологічного (емоціональний фон, в тому числі відчуття щастя або страждання), соціального (можливість участі в суспільній діяльності, контакти, обмеження можливостей за станом здоров'я в плані навчання, роботи, відпочинку), духовного благополуччя людини; загальне сприйняття стану свого здоров'я та благополуччя. Тобто, якість життя можна вважати суб'єктивним відчуттям, близьким до щастя й особистого благополуччя (Вірна, 2013).

Аналізуючи дослідження якості життя, С. Баженов і Н. Маліков (2002) вказують, що вони проводяться в цілому в двох напрямах: на базі об'єктивних умов життя і на основі вивчення ступеня задоволеності життям самими суб'єктами. Відповідно до зазначеної моделі, фахівці визначають якість життя як складну синтетичну категорію, що акумулює в собі усі істотні для особи умови існування та розвитку.

На нашу думку, найбільш повним та точним визначенням, що розкриває суть якості життя, $\epsilon$ те, що якість життя особистості - це сприйняття нею своєї життєвої позиції, а також фізичного, психічного та соціального благополуччя, залежно від якості середовища, в якому людина живе і рівня задоволення життям та іншими складовими психологічного комфорту. Слід зазначити, що психологічна сторона якості життя людини виявляється у тому, як сама людина визначає рамки свого благополуччя та переваги свого життя (Halian, 2019; Kaźmierczyk, 2019; Сердюк та ін., 2018; Чабан, 2008; Berenger, Verdier-Chouchane, 2007).

Таким чином, вивчення якості життя як психологічної категорії неможливо без звернення до поняття “задоволеність". Дане поняття практично не грає ролі в економічній теорії об’єктивної якості життя, тоді як в теорії суб'єктивної якості життя воно виходить на перший план, стаючи одним із ключових. Так, М. Аргайл визначив стан переживання задоволеності життям у цілому як щастя, розуміючи як загальну рефлексивну оцінку людиною свого минулого і теперішнього, а також частоту та інтенсивність позитивних емоцій (Аргайл, 2003). На думку вченого, значущими для задоволення 2003). In the scientist's opinion, the following 
factors are of importance for the satisfaction with life: significant social contacts, assessment of the social state, self-assessment of health, financial standing, an opportunity for creative manifestation, satisfaction with the professional activity, own prospects, leisure activity, personal growth, family (Argyle, 2003).

It is noteworthy that the satisfaction with life depends on the requirements for oneself, meeting the demands, level of aspirations, expectations from life as well as the possibilities to realize the personal endeavors; therefore, the criterion for the quality of life of a person is his or her satisfaction with life. Therefore, we understand life satisfaction as a state characterized by satisfying one's actual needs, the conformity of the level of ambitions to real possibilities and requirements to oneself and expectations from life as well.

Taking into account the axiological guidelines for assessing the quality of life, it was decided to divide it into two main approaches. An objective approach is the most common. It determines the quality of life through the indicators of objective conditions and processes of life. The purpose of this approach is to measure the level of the public life based on various statistical data. The objective indicators of the assessment of quality of life are evaluated by therelevantmethods. Thesemethodsdon'tdepend on an estimator's attitude to the properties of an object under assessment and are targeted at obtaining values from the standardized units of measurement. An objective assessment of economic factors of quality of life covers the indicators of material well-being, income; an average monthly salary, the subsistence level, the population with incomes below the subsistence level, the structure of cash income and expenditure of the population; housing, etc. The latter approach - subjective - involves characterizing quality of life following the sociological surveys. The subjective assessments provide a person's perception of the quality of life and rely on the subjective feelings, personal values. Some scientists distinguish the rational and emotional components of the subjective assessments. The former component consists of general satisfaction with life and assessment of satisfaction with different aspects of life. The latter component is the correlation of positive and negative emotions (Prystupa \& Kurysh, 2010). The subjective indicators життям такі фактори: наявність значущих соціальних контактів, оцінка соціального стану, оцінка власного здоров'я, оцінка матеріального стану, можливість проявляти творчість, задоволеність професійною діяльністю, власні перспективи, наявність дозвілля, особистісне зростання, наявність сім'ї (Аргайл, 2003).

Слід наголосити, що задоволеність життям залежить від вимог до себе, задоволення потреб, рівня домагань, очікувань від життя, а також від можливостей реалізації своїх прагнень, тому критерієм якості життя людини $є$ їі задоволеність життям. Таким чином, ми розуміємо під задоволеністю життям стан, який характеризується задоволенням своїх актуальних потреб, відповідністю рівня домагань реальним можливостям і вимогам до себе, а також очікувань від життя.

Із урахуванням ціннісних настанов до оцінювання якості життя ми поділяємо його на два основних підходи. Найбільш поширеним $€$ об'єктивний підхід. Він визначає якість життя через параметри об'єктивних умов і процесів життєдіяльності. Метою даного підходу є вимірювання рівня життя суспільства на основі різної статистичної інформації. Об'єктивні параметри оцінки якості життя вимірюються відповідними методами. Ці методи не залежать від ставлення оцінювача до властивостей об'єкту вимірювання та націлені на отримання значень у стандартизованих одиницях виміру. Об'єктивна оцінка економічних чинників якості життя охоплює показники матеріального добробуту, доходу; середньомісячної заробітної плати, розміру прожиткового мінімуму, чисельності населення з доходами нижчими за прожитковий мінімум, структури грошових доходів і витрат населення; забезпеченості житлом тощо. Другий підхід, суб'єктивний, передбачає охарактеризування якості життя на основі соціологічних опитувань. Суб'єктивні оцінки презентують індивідуальне сприйняття людиною якості життя та грунтуються на суб'єктивних відчуттях, особистих оцінках. Деякі науковці виділяють раціональну і емоційну складові у суб'єктивних оцінках. Перший компонент складається із загальної задоволеності життям і оцінок ступеня задоволеності різними сторонами

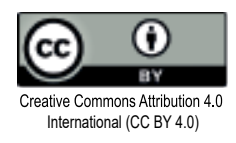


A person's quality of life and features of its measurement

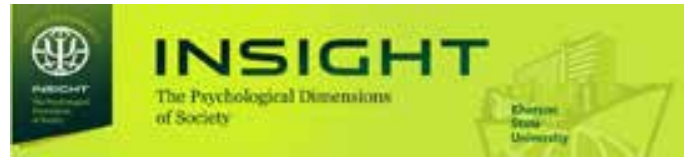

життя. Другий компонент є співвідеошенням позитивних і негативних емоцій (Приступа, Куриш, 2010). Суб'єктивні параметри оцінюються алгоритмами, що залежать від знань та накопиченого особистого життєвого досвіду, індивідуальних критеріїв оцінювання об'єктів, суб'єктів та явищ, життєвих цінностей і світогляду. Тому важливим $\epsilon$ вибір критеріїв, за якими людина повинна оцінювати якість свого життя, методологічний інструментарій узагальнення отриманих висловлювань і оцінок, визначення факторів, здатних впливати на усвідомлення відповідних станів індивіда тощо (Лібанова та ін., 2013). Отже, актуальність нашого дослідження визначається особливою значимістю досліджуваного поняття, а також запитом зі сторони суспільства, яке обумовлене бажанням кожної людини бути задоволеною та щасливою, а також необхідністю покращення якості життя особистості.

Метою статті $\epsilon$ висвітлення авторської моделі якості життя та представлення результатів апробації авторської методики “Вивчення якості життя особистості" для дослідження задоволеності та якості життя.

\section{Методологія}

Для діагностики показників якості життя ми розробили опитувальник на вивчення якості життя особистості, який містить 16 запитань, що стосуються оцінки задоволеності власним життям та якості життя. А також для визначення конкурентної валідності нашого опитувальника ми використовували тест життєстійкості ("Hardiness Survey") С. Мадді на вивчення оцінки здатності та готовності людини активно і гнучко діяти в ситуації стресу і труднощів, ступінь її уразливості до переживань та стресу (Леонтьев, Рассказова, 2006); шкалу самоефективності Р. Шварцера та М. Єрусалема на визначення рівня професійної самоефективності (Кокун та ін., 2011: 142-144); шкалу суб'єктивного щастя С. Любомирські для вимірювання рівня суб'єктивного щастя (Lyubomirsky, Lepper, 1999) та шкалу задоволеності життям (Е. Дінер, Р. Еммонс, Р. Ларсен, С. Гріффін) для вивчення вираженості суб'єктивної задоволеності життям людей (Diener et al., 1985).

\section{Participants}

117 persons from different regions of Ukraine participated in the empirical research: $41.9 \%$ men and 58.1\% - women of different professions aged from 19 to 40 years. According to 
the way of selection, the sample is random to avoid unintentional or deliberate distortion of the facts.

\section{Procedure and tools}

Animportantcomponentof the system of quality of life is the configuration of the environment and conditions under which a person's values are realized, human and social capital is formed. The environment of quality of life shapes opportunities for the person's development and establishes a degree of correspondence of living standards with the personal physiological and psychological needs and values (Libanova et al., 2013). Person's quality of life includes the standard of life which involves the following: health condition, leisure time, nutrition, services, housing conditions, level of education, public safety, movement safety, as well as living conditions: sanitary conditions, conditions for leisure, health care, ecology, mental state. Relying on the above, the beforementioned phenomenon has a complex structure.

Taking into account the forgoing, it was developed a model of quality of life, which is presented in figure 1. The model is based on the idea that the actual value of the quality of life is reflected in the subjective feelings of a person, and these feelings are developed through the prism of specific objective conditions (Chykhantsova, 2020). It should be emphasized that the subjective perception of different components of quality of life by individuals can markedly differ. Some conditions, which guarantee a decent life, are significant for one person and insignificant for another.

The quality oflife is a complex, multi-component phenomenon dependent both on objective factors (satisfaction of human needs and interests in these socio-economic conditions) and a wide range of subjective factors (psychological, social, sociocultural and others). The improvement of quality of life is a criterion and required condition for human development.

When interpreting the model, it was taken the opinion that the subjective and objective components of the quality of life more than coexist in one system - they reflect the same life spheres of a person from different perspectives. As a result, quality of life represents the basic preconditions and a degree of the implementation

\section{Учасники}

У емпіричному дослідженні взяли участь 117 осіб із різних регіонів України, із яких $41.9 \%$ - чоловіки та $58.1 \%$ - жінки, різних за фахом та віком від 19 до 40 років. За способом відбору - вибірка випадкова, оскільки ми намагалися уникнути ненавмисного або свідомого спотворення фактів.

\section{Процедура та інструменти}

Важливим компонентом системи якості життя виступає конфігурація середовища та умов, за яких реалізуються цінності особистості, формується людський та соціальний капітал. Середовище якості життя формує можливості розвитку, які надаються людині, а також визначає ступінь відповідності умов життедіяльності фізіологічним та психологічним потребам і цінностям людини (Лібанова та ін., 2013). Якість життя людини включає рівень життя до якого належать: стан здоров'я, вільний час, харчування, послуги, житлові умови, рівень освіченості, суспільна безпека, безпека пересування, а також умови життя: санітарні умови, умови для проведення дозвілля, охорона здоров'я, екологія, психічний стан. Виходячи з наведеного, вище зазначений феномен має складну структуру.

Отже, з огляду на вище сказане, ми розробили модель якості життя, яка представлена на рисунку 1. Наша модель побудована на твердженні, що дійсне значення якості життя відображене в суб'єктивних відчуттях людини, а ці відчуття формуються на основі конкретних об'єктивних умов (Chykhantsova, 2020). Також слід звернути увагу на те, що суб'єктивне сприйняття різних компонентів якості життя окремими людьми може дуже відрізнятися. Так, деякі умови, які забезпечують достойне життя, $\epsilon$ значимі для однієї людини, можуть бути невагомими або малозначимими для іншої.

Так, якість життя виступає складним, багатокомпонентним явищем, залежним як від об'єктивних факторів (задоволення людських потреб та інтересів у даних соціально-економічних умовах), так і від різноманітних суб'єктивних факторів (психологічних, соціальних, соціокультурних та інших). Підвищення рівня якості життя виступає критерієм і необхідною умовою людського розвитку.

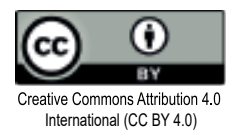




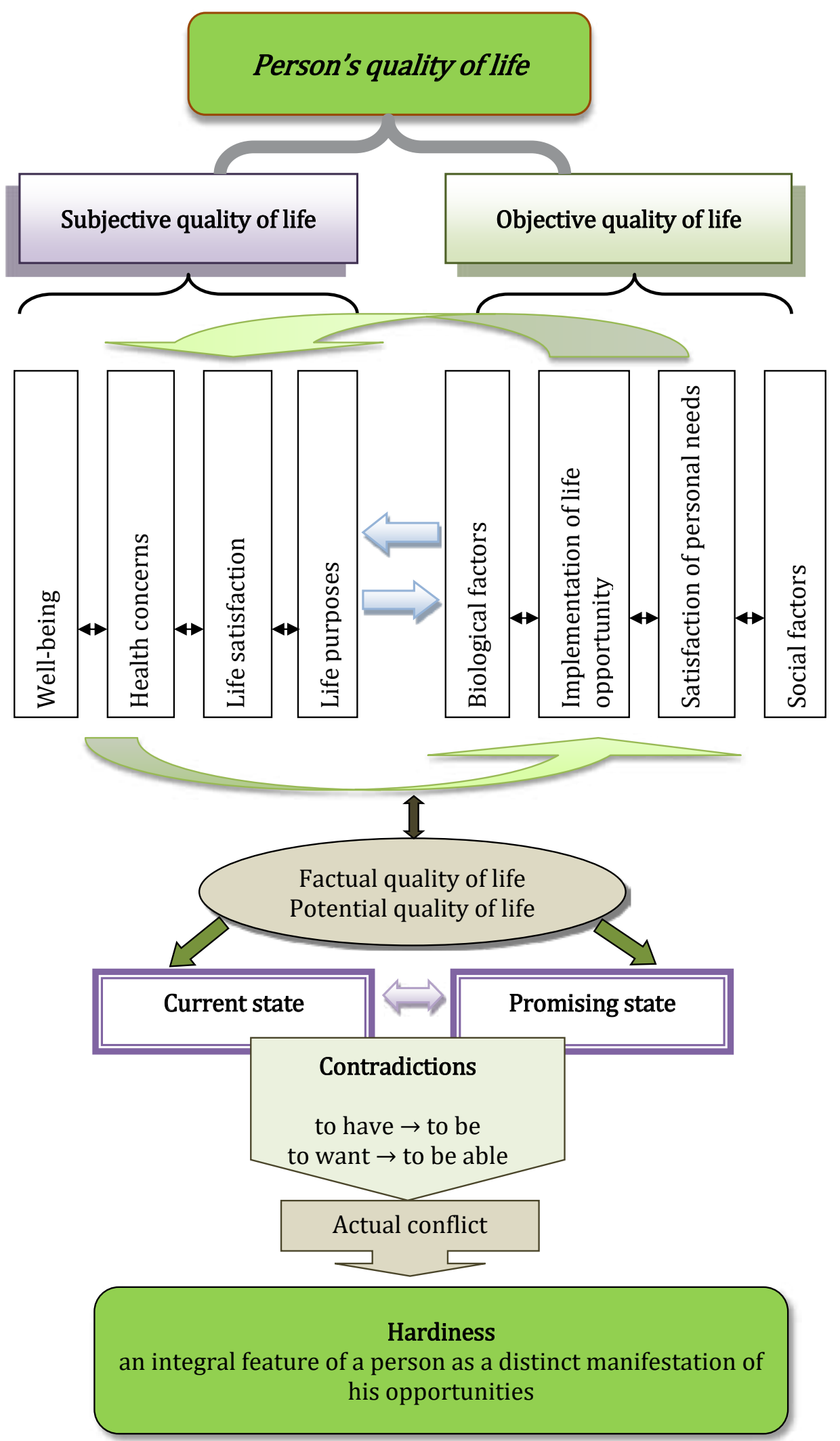

Fig. 1. Person's quality of life model 

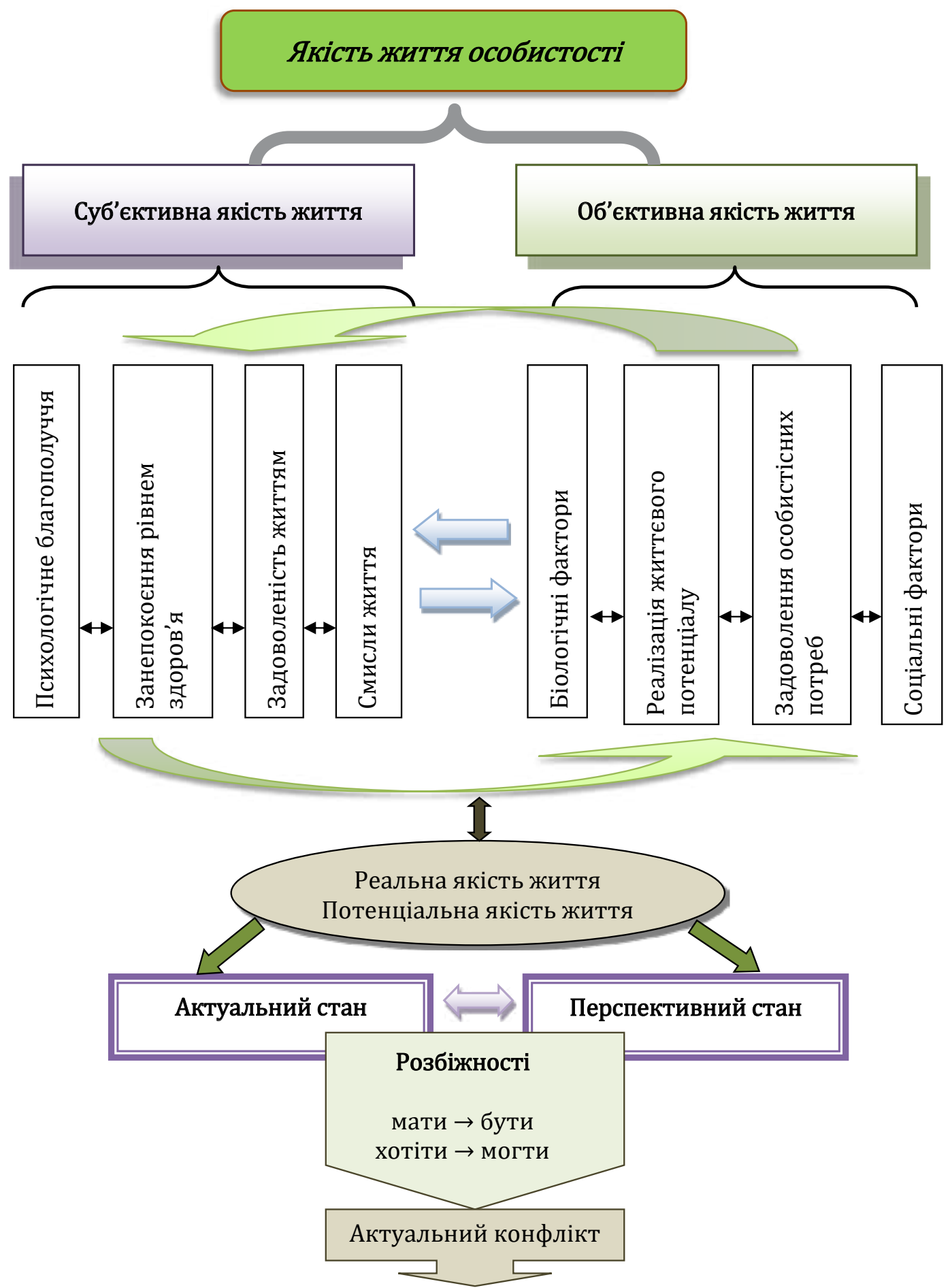

Життєстійкість (Hardiness)

інтегральна характеристика особистості,

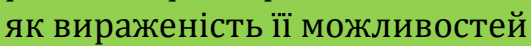

Рис. 1. Модель якості життя особистості 
A person's quality of life and features of its measurement of requirements for human development, the order of priority of the development in the cultural process, self-identity as well as the self-actualization and hardiness (Chykhantsova, 2018; Serdiuk et al., 2019). The achievement of a high level of personal quality of life is impossible without maintaining a high level of hardiness (Chykhantsova, 2018). Thus, quality of life is considered as a system of indices, which characterize a degree of implementation of living strategies of a person and meeting his or her vital demands.

The above-stated visions of quality of life determine the specifics and way of diagnosing the relevant phenomenon. To be sure, the peculiarities of the current state of the methodological aspect of this problem were taken into account as there is a sufficient quantity of valid procedures of psychodiagnostics which have contributed to the elaboration of substantial empirical data on the level of personal quality of life. However, these methods do not allow obtaining qualitative and quantitative information about the quality of life of a personality to its full extent and do not involve examining the person's needs, his or her search for life purpose and drive for happiness.

\section{Procedure and tools}

Guided by our well-founded theoretical approach to the study of life quality in the development of "Person's Quality of Life Questionnaire", we have changed from an analytical method of diagnosing quality of life to a systemic one. Following the fact that the method is investigative, it doesn't provide for the determination of a degree of manifestation of the parameters under diagnostics, their standardizing, and transformation into standard indicators. At the same time, the method makes it possible to define the conceptual, qualitative and quantitative characteristics of case qualities. We tried to identify a general degree of expression of the level of quality of life, taking into account the conceptual characteristics of quality of life. Due to the heterogeneous nature of a person's quality of life, it is impossible to characterize it in a clear way through the quantitative parameters. Thus, it has been decided to cover the structural characteristic of the quality of life as well.

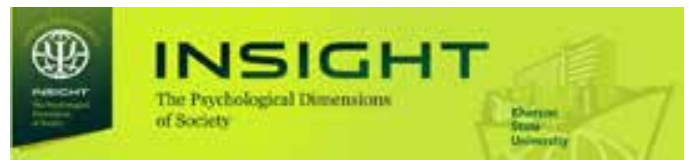

Трактуючи нашу модель, ми дотримуємося думки, що суб'єктивна й об'єктивна складові якості життя не просто співіснують в одній системі, вони з різних сторін відображають одні й ті ж сфери життя людини. Таким чином, якість життя відображає базові передумови та ступінь реалізації вимог розвитку людини, ступінь пріоритетності розвитку у культурному процесі, самоідентичність, а також самопізнання людини та життєстійкість (Чиханцова, 2018; Serdiuk et al., 2019). Досягнення високого рівня якості життя людини не можливе без утвердження високого рівня життєстійкості (Чиханцова, 2018). Так, якість життя розглядається як система показників, які характеризують ступінь реалізації життєвих стратегій людини та задоволення ії життєвих потреб.

Викладені вище уявлення про якість життя визначають специфіку та спосіб діагностування зазначеного явища. Звичайно, ми прийняли до уваги особливості сучасного стану методичного аспекту даної проблеми, оскільки створено достатньо валідних психодіагностичних процедур, за допомогою яких отримано значний емпіричний матеріал про рівень якості життя людини. Однак ці методи не дозволяють у повній мірі отримати якісну та кількісну інформацію про якість життя особистості та не передбачають дослідження потреби особистості, пошук людиною сенсу життя та її прагнення до щастя.

\section{Процедура та інструменти}

При розробці опитувальника "Вивчення якості життя особистості" ми керувалися обгрунтованим нами теоретичним підходом до дослідження якості життя, який дозволяє перейти від аналітичного способу діагностики якості життя до системного. Оскільки наша методика $\epsilon$ дослідницькою, тому нами не передбачено визначення ступеня вираженості діагностованих параметрів, їх нормування, а також переведення в стенові показники. Хоча методика дозволяє визначити змістові, якісні, кількісні характеристики досліджуваних якостей. Ми намагалися визначити загальну ступінь вираженості рівня якості життя, враховуючи змістові характеристики якості життя. Через гетерогенний характер якості життя особистості, iї 
Based on the approved model, it has been chosen a way specifying a list of indices revealing the subject-matter of diagnostics. The use of the method of free associations has given an option of proposing a list of the questions for elucidating indices of the personal quality of life, which have laid the groundwork for the formulation of 35 statements. Having used the factor analysis, identical statements have been rejected and the final version of the questionnaire, which contains 16 statements to be evaluated following 7-point grading scale, has been adopted: 1 point - very low level; 2 points - low level; 3 points - below the average; 4 points - average level; 5 points - above the average; 6 points high level; 7 points - very high level. For instance, evaluate satisfaction with your life in general, satisfaction with your family life, satisfaction with your study (work, professional activity), evaluate the relationship with relatives and family and the level of quality of life in general. The questionnaire does not provide questions that can be used to detect insincerity of a respondent. When counting the number of points, the total points are summed both in the actual and potential dimensions, because they make a certain contribution to this indicator. The statements include the calculation of points on a direct scale.

\section{Statistical analysis}

Statistical processing of empirical data and graphical presentation of results have been carried out using the statistical programs "SPSS" v. 21.0 and "MS Excel".

Statistical processing of data obtained has been based on the sample involving 117 persons. The wording of statements is similar both for women and men. The age varies from 19 years and older. The statistical characteristics of the sample can be regarded to be suitable for assessing the level of diagnosed indices.

\section{Results}

The building of the standard scale

The reliability of the method of studying a person's quality of life according to the level on inner coherence of the statements (Cronbachs alpha) is high $(\alpha=.802)$. Descriptive statistics of "Person's quality of life questionnaire" are presented in table 1 . неможливо чітко охарактеризувати лише кількісними параметрами, тому ми вирішили також розкрити структурну характеристику якості життя.

На основі прийнятої нами моделі, ми обрали спосіб визначення переліку індикаторів, що розкривають предмет діагностики. Використавши метод вільних асоціацій, було сформульовано перелік питань для виявлення індикаторів якості життя людини, які слугували у подальшому для побудови тверджень опитувальника. Як наслідок, було сформовано 35 тверджень. Використавши факторний аналіз, було відкинуто тотожні твердження та визначено остаточний варіант опитувальника, що налічує 16 тверджень, які потрібно оцінити за 7-ю шкалою: 1 бал - дуже низький рівень; 2 бали - низький рівень; 3 бали - нижче середнього; 4 бали-середнійрівень; 5 балів-вище середнього; 6 балів-високий рівень; 7 балів-дуже високий рівень. Наприклад, оцініть задоволеність своїм життям у цілому, задоволеність своїм сімейним життям, задоволеність своїм навчанням (своєю робою, професійною діяльністю), оцініть взаємостосунки з близькими та сім'єю та рівень якості життя у цілому. Опитувальник не передбачає запитання за допомогою яких можна виявити нещирість респондента. При підрахунку кількості балів складається сума балів як в актуальному, так і в потенційному вимірі, оскільки вносять визначений вклад в даний показник. Твердження передбачають підрахунок балів за прямою шкалою.

\section{Статистичне аналізування}

Статистичну обробку емпіричних даних і графічну презентацію результатів здійснено за допомогою статистичних програм "SPSS" v. 21.0 та "MS Excel".

Статистична обробка отриманих даних була проведена на вибірці із 117 осіб. Формування речень однакові як для жінок, так і чоловіків. Віковий діапазон - 19 років і старше. Вважаємо, що статистичні характеристики даної вибірки можна вважати придатними для визначення рівнів діагностованих показників.

\section{Результати}

Побудова нормативної шкали.

Надійність методики вивчення якості життя особистості за рівнем внутрішньої узгодженості

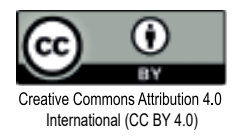


Table 1. Descriptive statistics of "Person's quality of life questionnaire" (n=117)

Таблиця 1. Описові статистики опитувальника “Вивчення якості життя" (n=117)

\begin{tabular}{|c|c|c|c|c|c|}
\hline $\begin{array}{c}\text { Scale } \\
\text { Шкала }\end{array}$ & $\begin{array}{c}\text { Average value } \\
\text { Середнє } \\
\text { значення }\end{array}$ & $\begin{array}{c}\text { Мinimum value } \\
\text { Мінімальне } \\
\text { значення }\end{array}$ & $\begin{array}{c}\text { Махіmum value } \\
\text { Максимальне } \\
\text { значення }\end{array}$ & $\begin{array}{c}\text { Standard } \\
\text { deviation } \\
\text { Стандартне } \\
\text { відхилення }\end{array}$ & $\begin{array}{c}\text { Variation } \\
\text { соеfficient } \\
\text { Коефіцієнт } \\
\text { варіації }\end{array}$ \\
\hline $\begin{array}{c}\text { Quality of life } \\
\text { Якість життя }\end{array}$ & 70.87 & 16.0 & 112.0 & 13.91 & $25.0 \%$ \\
\hline
\end{tabular}

The research has also examined for compliance with the normal distribution (the KolmogorovSmirnov test). As the indices meet these criteria, the standard values of quality of life are formed under the 3-sigma rule. In accordance with the Gaussian distribution, $99.6 \%$ of the statistical population data is within $3 \sigma, 94.0 \%$ - within $2 \sigma$, and $68.0 \%$ - within $1 \sigma$. For the sample, $X \pm S_{x}$ is regarded as an average value of the indicator, $\mathrm{X}+2 \mathrm{~S}_{\mathrm{X}}-$ as a high value, $\mathrm{X}-1 \mathrm{~S}_{\mathrm{x}}-$ as a low value, and $X \pm 3 S_{x}$ - as very high and very low values, where $X$ - an arithmetical mean; S - a standard deviation (Serdiuk, 2012).

Following the calculations, the values are distributed as follows (see figure 2).

Consequently, the levels of quality of life have the following values: low quality of life 16-56 points, average quality of life $-57-58$ points, high quality of life $-86-112$ points. тверджень (альфа Кронбаха) є високою ( $\alpha=.802)$. Описові статистики “Опитувальника вивчення якості життя" наведено у таблиці 1.

Також була здійснена перевірка на відповідність закону нормального розподілу (критерій Колмогорова-Смірнова). Оскільки показники відповідають цим критеріям, то нормативні значення показника якості життя визначатимуться за правилом 3б. Відповідно до закону нормального розподілу К. Гауса, в межах $3 \sigma$ знаходиться 99.6\% даних генеральної сукупності, в межах $2 \sigma$ знаходиться $94.0 \%$ і в межах $1 \sigma-68.0 \%$. Тому для вибірки середніми значеннями показників будемо вважати $\mathrm{X} \pm \mathrm{S}_{\mathrm{x}}$, високими значеннями будемо вважати $\mathrm{X}+2 \mathrm{~S}_{\mathrm{x}}$, низькими значеннями - $\mathrm{X}-1 \mathrm{~S}_{\mathrm{x}}$, і $\mathrm{X} \pm 3 \mathrm{~S}_{\mathrm{x}}$ відповідно дуже високими і дуже низькими значеннями, де X - середнє арифметичне; S - стандартне відхилення (Сердюк, 2012).

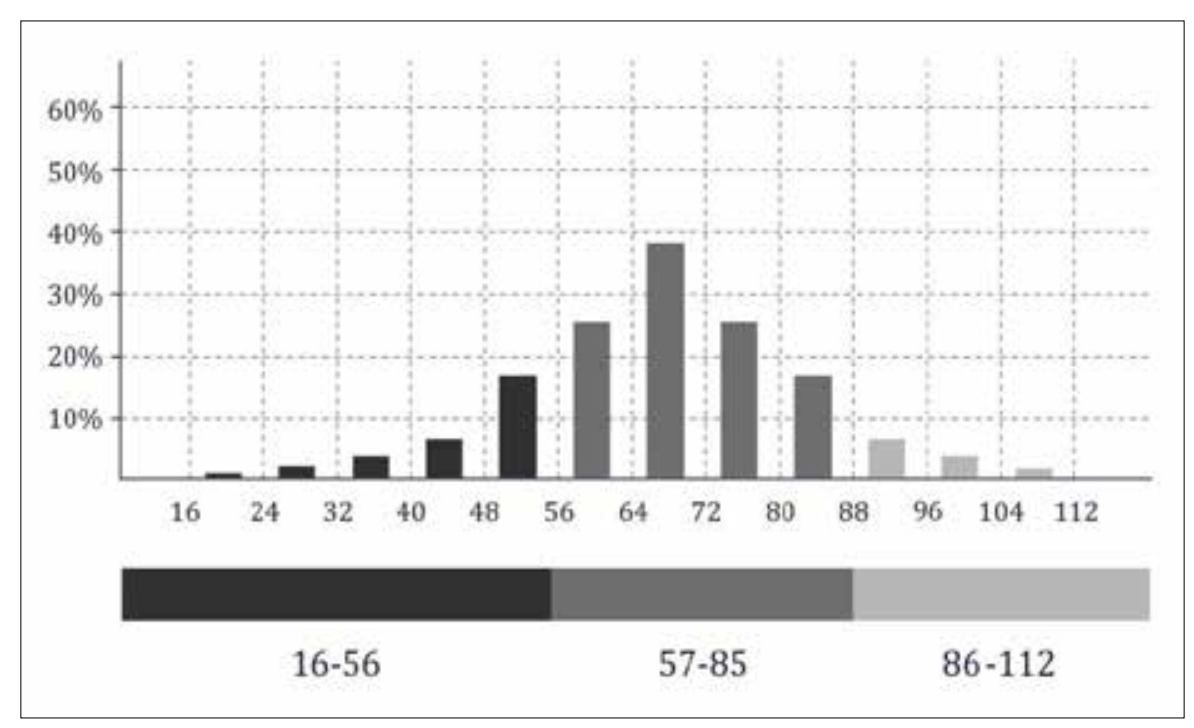

Fig. 2. Values of the quality of life levels

Рис. 2. Значення рівнів якості життя

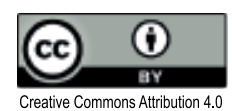


When rendering obtained points, one can state that a high level (86-112 points) is characterized by the satisfaction with one's needs and compliance of real opportunities with expected. A feature of the high level of quality of life includes good living conditions, favorable conditions for recreation and leisure, an advanced level of education and culture, qualitative medical care and social security, public care for children and motherhood, protection of life safety and property rights. Accordingly, low points (16-56) indicate the opposite characteristics.

\section{Reliability and validity of output data of the method}

The reliability of the method has been checked by re-interviewing the participants in two months. The correlation between the results of the former and later testing is $r=.78$ that confirms testretest reliability of the questionnaire. Therefore, the method can be considered as reliable as the least acceptive value for retest reliability is .7 (Serdiuk, 2012).

To identify concurrent validity, it has been calculated the correlation coefficients between the obtained indicators and similar indices of individual scales of the test methods: Hardiness Test by S. Maddi, General Self-Efficacy Scale (R. Schwarzer, M. Jerusalem), Lyubomirsky's Subjective Happiness Scale, Satisfaction with Life Scale (E. Diener, R. Emmnos, R. Larsen and S. Griffin) (see table 2).

Having applied the correlation analysis, we defined the natural relationships between these indicators. In particular, it is marked the positive interrelation between the quality of life and hardiness $(r=.736$;
Відповідно розрахункам значення розподілятимуться наступним чином (див. рис. 2).

Отже, рівні якості життя матимуть наступні показники: низький рівень якості життя - 16-56 балів, середній рівень якості життя - 57-58 балів, високий рівень якості життя - 86-112 балів.

Трактуючи отримані бали, ми можемо сказати, що високий рівень (86-112 балів) характеризується задоволеністю потреб людини і відповідністю реальних можливостей очікуваним. Також ознакою високого рівня якості життя $\epsilon$ хороші житлово-побутові умови, гарні умови відпочинку і використання вільного часу, високий рівень освіти і культури, якісне медичне обслуговування, якісне соціальне забезпечення, піклування суспільства про дітей і материнство, захист безпеки життя і прав власності. Відповідно, низькі бали (16-56) вказуватимуть на протилежні характеристики.

Надійність та валідність вихідних даних методики.

Надійність методики перевірялась повторним опитуванням досліджуваних через два місяці. Кореляція між результатами першого та другого тестування виявилася на рівні $\mathrm{r}=.78$, що свідчить про ретестову надійність опитувальника. Тому, методику можна вважати надійною, оскільки найменшим задовільним значенням для ретестової надійності є.7 (Сердюк, 2012).

Для визначення конкурентної валідності розраховувались коефіцієнти кореляції

Table 2. The Pearson correlation coefficients between the indices of alternative methods $(\mathrm{n}=117)$

Таблиця 2. Значення коефіцієнтів кореляції Пірсона між показниками альтернативних методик (n=117)

\begin{tabular}{|c|c|c|c|c|}
\hline $\begin{array}{c}\text { Scale } \\
\text { Шкала }\end{array}$ & 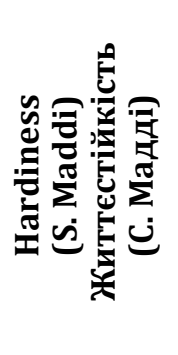 & 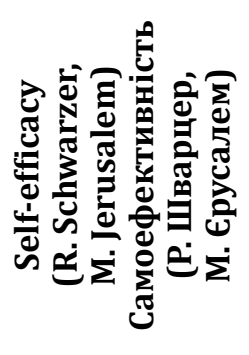 & 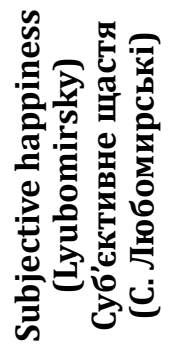 & 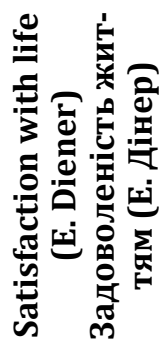 \\
\hline $\begin{array}{l}\text { Quality of life } \\
\text { Якість життя }\end{array}$ & $.736^{* *}$ & $.629^{*}$ & $.659^{* *}$ & $.707^{* *}$ \\
\hline
\end{tabular}

Note: ${ }^{* *}$ correlation significance level $\leq 0.01{ }^{*}$ correlation significance level $\leq 0.05$

Примітка: ${ }^{*}$ кореляція значуща на рівні $0.01 ;{ }^{*}$ кореляція значима на рівні 0.05 
A person's quality of life and features of its measurement

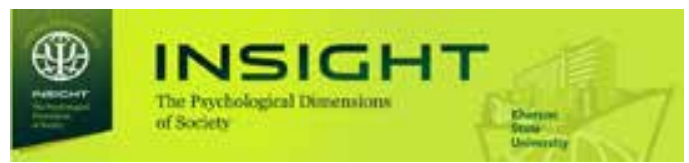

між отриманими показниками та подібними показниками окремих шкал тестових методик: тест життєстійкості С. Мадді, шкала самоефективності Р. Шварцера та М. Єрусалема, шкала суб'єктивного щастя С. Любомирські, шкала задоволеності життям (Е. Дінер, Р. Еммонс, Р. Ларсен, С. Гріффін) (див. табл. 2).

Застосувавши кореляційний аналіз ми визначили закономірні взаємозв'язки між зазначеними показниками. Зокрема, виділено позитивний взаємозв'язок між якістю життя та життєстійкістю (r=.736; ps.01), тобто, чим вищий рівень життєстійкості, тим вищою $\epsilon$ якість життя досліджуваних. У досліджуваних також було зафіксовано позитивні кореляційні зв'язки між показниками задоволеності життям ( $\mathrm{r}=.707 ; \mathrm{p} \leq .01)$, суб'єктивним щастям (r=.659; $\mathrm{p} \leq .01)$ і самоефективністю (r=.629; $\mathrm{p} \leq .05)$. Високі показники взаємозв'язку досліджуваних параметрів свідчать про об'єктивність отриманих даних та дають підстави вважати авторську методику придатною для майбутнього використання.

Варто наголосити, що щастя є одним із важливих показників при ідентифікації задоволення життям людей. У ході дослідження ми виявили, що 28,2\% досліджуваних почуваються щасливими, 34,2\% - досить щасливими і $37,6 \%$ - нещасними. Результати дослідження підтверджують, що чим вища у людей якість життя (за їх власним

Table 3. The interrelations between quality of life and objective and subjective factors ( $\mathrm{n}=117)$

Таблиця 3. Взаємозв'язки якості життя з об'єктивними та суб'єктивними факторами $(\mathrm{n}=117)$

\begin{tabular}{|c|c|c|c|c|c|c|c|c|}
\hline $\begin{array}{c}\text { Scale } \\
\text { Шкала }\end{array}$ & 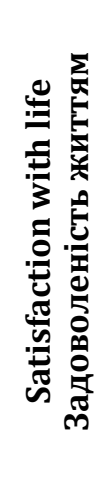 & 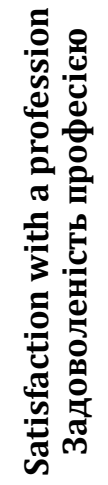 & 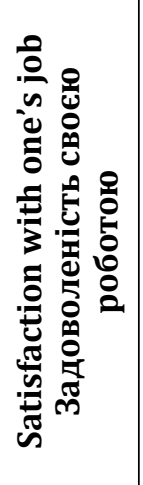 & 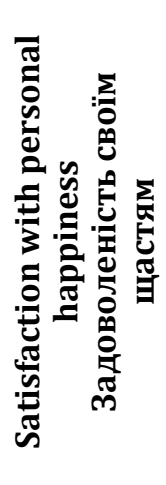 & 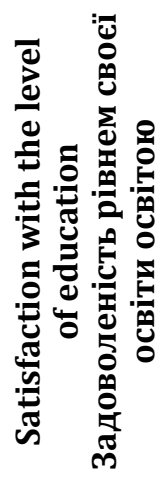 & 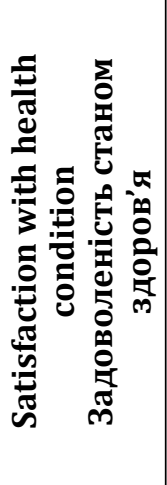 & 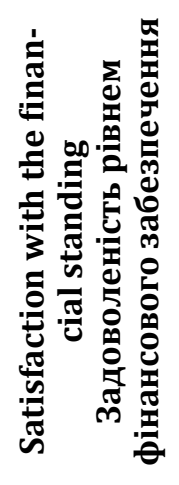 & 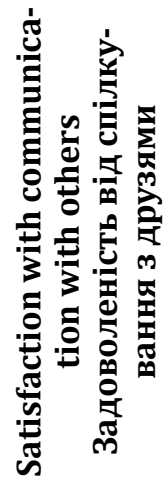 \\
\hline $\begin{array}{l}\text { Quality of life } \\
\text { Якість иття }\end{array}$ & $.749^{* *}$ & $.556^{* *}$ & $.617^{* *}$ & $.583^{* *}$ & $.553^{* *}$ & $.648^{* *}$ & $.617^{* *}$ & $.435^{* *}$ \\
\hline
\end{tabular}

Note: ${ }^{* *}$ correlation significance level $\leq 0.01$

Примітка: ${ }^{* *}$ кореляція значуща рівні 0.01

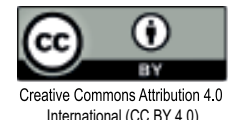


$(\mathrm{r}=.747 ; \mathrm{p} \leq .01)$. Quality of life also depends on the satisfaction with personal health condition $(\mathrm{r}=.648 ; \mathrm{p} \leq .01)$, satisfaction with a profession $(\mathrm{r}=.556 ; \mathrm{p} \leq .01)$ and satisfaction with the financial standing $(\mathrm{r}=.617 ; \mathrm{p} \leq .01)$. Based on the results of this research, we can conclude that the happier a person is, the higher is quality of his or her life $(\mathrm{r}=.583 ; \mathrm{p} \leq .01)$. It is interesting to state that communication with friends scarcely affects the quality of life $(r=.435 ; \mathrm{p} \leq .01)$.

\section{Discussion}

The feature of measuring quality of life is that it can be carried out in two ways: by assessing the objective living conditions and assessing the subjective living conditions. Human needs and interests are individual and a degree of their satisfaction can be evaluated only by the subjects themselves. They are not fixed by any statistical values and exist in the consciousness of people and thus, in their personal thoughts and judgements. Moreover, the measurement of quality of life has two forms: a degree of meeting subjective needs and interests and subjective satisfaction with person's quality of life. In other words, quality of life is assessed through the objective and subjective indices. We can state that subjective quality of life indicates how well a person feels and is satisfied in general. The objective quality of life is the correspondence of public and cultural requirements with tangible wealth, social status and physical well-being.

Having regard to the above indices of the interrelation of quality of life with other indicators under study, we highlight the impartiality of data obtained. The application of other methods of psychodiagnostics and representativeness of the sample give the grounds to consider “Person's Quality of Life Questionnaire" to be expedient for studying quality of life. It should be emphasized that the assessment of quality of life renders the individual perception of the mentioned phenomenon and relies on the subjective feelings and personal judgements. Moreover, the research procedure includes the adjustment options, which involves recognizing the key concepts of one's own life, satisfaction with life, level and quality of a person's life.

Keeping in mind questionnaire's outcomes, we state that quality of life often has an overshoot оцінюванням), то тим щасливішими вони себе почувають.

Слід зазначити, що оцінка якості життя $є$ відносною. Визначення людиною ступеня задоволення своїх потреб грунтується на її життєвому досвіді, рівні культурного, інтелектуального, емоційного розвитку. Так, якість життя виражається як психологічне благополуччя, в якому людина відчуває внутрішнє задоволення від умов її життя (Chykhantsova, 2020).

За допомогою нашого опитувальника “Вивчення якості життя особистості” ми підтвердили думку про те, що якість життя виступає багатокомпонентним явищем, залежним від об'єктивних і суб'єктивних чинників (див. табл. 3).

Як і зазначалося вище, критерієм якості життя є задоволеність життям, що і було підтверджено ( $\mathrm{r}=.747 ; \mathrm{p} \leq .01)$. Також якість життя залежить від задоволеності станом свого здоров'я ( $\mathrm{r}=.648 ; \mathrm{p} \leq .01)$, задоволеності професією ( $\mathrm{r}=.556 ; \mathrm{p} \leq .01)$ та задоволеністю фінансовим станом ( $\mathrm{r}=.617 ; \mathrm{p} \leq .01)$. Із отриманих результатів, ми можемо зробити висновок, що чим щасливішою почуває себе людина, тим вище буде якість іiі життя (r=.583; $\mathrm{p} \leq .01)$. Цікавим виявився той факт, що спілкування з друзями особливо не впливає на якість життя $(\mathrm{r}=.435 ; \mathrm{p} \leq .01)$.

\section{Дискусія}

Особливість вимірювання якості життя полягає у тому, що ї̈ можна провести двома способами: вимірюванням об'єктивних умов життя і вимірюванням суб’єктивних оцінок життя. Потреби та інтереси людей індивідуальні та ступінь їх задоволення можуть оцінити тільки самі суб'єкти. Вони не фіксуються будь-якими статистичними величинами і практично існують лише в свідомості людей, і відповідно, в їх особистих думках і оцінках. Таким чином, оцінка якості життя виступає в двох формах: ступінь задоволення об'єктивних потреб та інтересів і суб'єктивна задоволеність якістю життя самої особистості. Тобто, якість життя оцінюється за допомогою об'єктивних та суб'єктивних показників. Можна сказати, що суб'єктивна якість життя вказує на те, на скільки добре себе почуває людина і $\epsilon$ задоволеною речами у загальному.

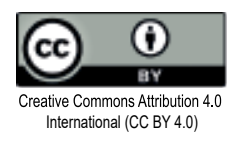


A person's quality of life and features of its measurement

effect, i.e. the person's satisfaction with one sphere of quality of life influences the level of satisfaction in other spheres. For instance, a high quality of professional engagement $(\mathrm{r}=.556 ; \mathrm{p} \leq .01)$ and satisfaction with a job $(\mathrm{r}=.617 ; \mathrm{p} \leq .01)$ boost the satisfaction with the whole life (see table 3 ).

Consequently, quality of life is understood as a complex characteristic, an integral index characterizing a degree of development and fulfillment of the whole set of needs and interests of the person. In this regard, we treated the concept of quality of life as a psychological category, i.e. how the person subjectively feels, percepts, evaluates the quality of his life, and elaborated the relevant method of psychodiagnostics for measuring the personal quality of life.

\section{Conclusions}

Psychologists often consider quality of life as a synonym for subjective well-being or satisfaction with life. At the same time, the major task of the diagnostic assessment is to determine the general level of subjective wellbeing of a particular person without taking into account an objective situation, and the structure of diagnostic tool is stipulated by the theoretical model according to a researcher's preference. Approaches to the definition and diagnosis of the quality of life in the human sciences are gradually converging that requires of psychology both mastering tools of other sciences and understanding the basic features, capabilities and limitations of such diagnostics.

To understand the concept of a person's quality of life, we outlined its components: subjective (psychological well-being, concern about health condition, life satisfaction, life purposes) and objective (biological factors, implementation of life plan, satisfaction with personal needs, social contacts). Thus, investigating quality of life as integral characteristic of the objective and subjective indices of human life, we found out the special significance for mental health of the very subjective assessment of quality of life which is manifested in the perception and attitude of the person to specific conditions and changes in life that determines mental and moral satisfaction with his or her life.

As a result of the practical evaluation of "Person's Quality of Life Questionnaire", it

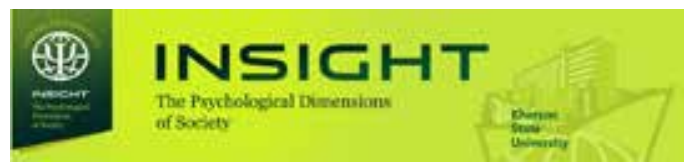

Об'єктивна якість життя полягає у відповідності суспільних та культурних вимог до матеріального багатства, соціального статусу та фізичного самопочуття.

Виходячи із вище наведених показників взаємозв'язку якості життя 3 іншими досліджуваними параметрами, ми можемо стверджувати про об'єктивність отриманих даних. А також застосування інших психодіагностичних методик та репрезентативність вибірки дають нам підстави вважати методику “Вивчення якості життя особистості" доцільною для дослідження якості життя. Також, слід зазначити, що оцінка якості життя відображає індивідуальне сприйняття зазначеного феномена та грунтуються на суб'єктивних відчуттях і особистих оцінках. Крім того, в процедурі дослідження є корекційні можливості, які полягають в усвідомленні ключових понять власного життя, задоволеності життям, рівня та якості життя особистості.

Ми можемо констатувати, виходячи із результатів нашого опитування, що якість життя часто має надлишковий ефект, тобто, задоволеність людини однією сферою якості життя впливає на рівень задоволеності в інших сферах. Наприклад, висока якість професійної зайнятості $(\mathrm{r}=.556 ; \mathrm{p} \leq .01)$ та задоволеність своєю роботою (r=.617; p $\leq .01)$ підвищують задоволеність усією якістю життя (див. табл. 3).

Отже, під якістю життя ми розуміємо комплексну характеристику, інтегральний показник, що характеризує ступінь розвитку і повноту задоволення всього комплексу потреб та інтересів особистості.У зв'язку з цим ми розглядали поняття якості життя як психологічну категорію, тобто яким чином особистість суб'єктивно відчуває, сприймає, оцінює якість свого життя та розробили відповідну психодіагностичну методику для вимірювання рівня якості життя особистості.

\section{Висновки}

Якість життя дуже часто розглядається психологами як синонім суб’єктивного благополуччя або задоволеність життям. Основним завдання діагностики при цьому $є$ виявлення загального рівня суб'єктивного благополуччя 
is applied such tools which permit identifying the level of the person's quality of life and analysing its features. The statistical data processing clarifies the positive interrelation between the indices of quality of life and hardiness, the indices of life satisfaction and subjective happiness, and selfefficacy.

The method of psychodiagnostics "Person's Quality of Life Questionnaire" meets modern demands on the psychometric substantiation of the personal questionnaires and has high test-retest reliability (.7). It can be used for defining the levels of quality of a person's life. The standardization of "Person's Quality of Life Questionnaire" has shown a high reliability $(\alpha=.802)$ and validity.

\section{References:}

Argyle, M. (2003). Psychology of happiness. St. Petersburg: Peter.

Baranauskienè, I., Serdiuk, L. \& Chykhantsova, 0. (2016). Psychological characteristics of school-leavers' hardiness at their professional self-determination. Social welfare: Interdisciplinary approach, 6 (2), 64-73. DOI: 10.21277/ sw.v2i6.275

Bazhenov, S. A. \& Malikov, N. S. (2002). Quality of life of the population: theory and practice. Living standards of the population of the regions of Russia, 2, 1-46.

Berenger, V. \& Verdier-Chouchane, A. (2007). Multidimensional Measures of Well-Being: Standard of Living and Quality of Life Across Countries. World Development, 35 (7), 1259-1276.

Chaban, O. S. (2008). Quality of life of the patient from the standpoint of medical psychology. The art of healing, 5(51), 40-43.

Chykhantsova, O. (2018). Hardiness and its connection with personal values. Problems of modern psychology, 42, 211-231. DOI: 10.32626/2227-6246.201842.211-231

Chykhantsova, 0. (2020). The personal quality of life and life satisfaction. The $3_{r d}$ International scientific and practical conference - Scientific Congress (March 22-24, 2020) Barca Academy Publishing, Barcelona, Spain, 304-307.

Diener, E., Emmons, R., Larsen, R. et al. (1985). The Satisfaction with Life Scale. Journal of Personality Assessment, 49,71-75.

Halian, I. (2019). Personal determinants of responsibility of future educators. Insight: the psychological dimensions of society, 1, 15-21. DOI: 10.32999/2663-970X / 2019-1-2 окремої людини, зазвичай без врахування об'єктивної ситуації, а структура діагностичного інструменту задається бажаною дослідником теоретичною моделлю. Підходи до визначення та діагностики якості життя в науках про людину поступово зближуються, що вимагає від психології як оволодіння інструментарієм різних наук, так і розуміння основних особливостей, можливостей і обмежень такої діагностики.

Для розуміння поняття якості життя особистості ми окреслили їі складові: суб'єктивна (психологічне благополуччя, занепокоєння рівнем здоров'я, задоволеність життям, смисли життя) та об'єктивна (біологічні фактори, реалізація життєвого плану, задоволення особистісних потреб, соціальні контакти). Таким чином, досліджуючи якість життя як інтегральну характеристику об'єктивних і суб'єктивних індикаторів життя людини, ми виявили особливу значимість для психічного здоров'я саме суб'єктивної оцінки якості життя, що виявляється в сприйнятті та ставленні особистості до певних умов та змін у житті, що визначає душевне і моральне задоволення власним життям.

У результаті проведеної апробації опитувальника "Вивчення якості життя особистості” для дослідження якості життя отримано такий інструментарій, який дає змогу виявити рівні якості життя особистості, а також здійснити аналіз іiі особливостей. За допомогою статистичного опрацювання даних виявлено позитивний взаємозв'язок між показниками якості життя та життєстійкістю, між показниками задоволеності життям, суб'єктивним щастям і самоефективністю.

Психодіагностична методика "Вивчення якості життя особистості” відповідає сучасним вимогам до психометричного обгрунтування особистісних опитувальників та має високу ретестову надійність (.7) і може використовуватись для визначення рівнів якості життя особистості. Стандартизація опитувальника "Вивчення якості життя особистості" показала його високу надійність $(\alpha=.802)$ та валідність.

Список використаних джерел

Аргайл М. Психология счастья. Санкт-Петербург: Питер. 2003. 332 с.

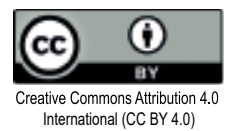


A person's quality of life and features of its measurement

Kaźmierczyk, J. (2019). Work force segmentation model: banks' example. Entrepreneurship and Sustainability Issues, 6 (4), 1938-1954. DOI: 10.9770/ jesi.2019.6.4(28)

Kokun, O. M, Pishko, I. O, Lozinska, N. S., Kopanitsa, O. V. \& Malkhazov, O. R. (2011). Collection of methods for diagnostics of psychological readiness of servicemen of military service under the contract to activity as a part of peacekeeping units. Kyiv: NDC GP ZSU.

Leontiev, D. A. \& Rasskazova, E. I. (2006). Hardiness test. Moscow: Smysl.

Libanova, E. M., Gladun, O. M, Lisogor, L. S et al. (2013). Measuring the quality of life in Ukraine. Analytical report: monograph. Kyiv.

Lyubomirsky, S. \& Lepper, H. S. (1999). A measure of subjective happiness: Preliminary reliability and construct validation. Social Indicators Research, 46(2), 137-155. DOI: 10.1023/A:1006824100041

Prystupa, Ye. \& Kurish, N. (2010). Quality of human life: categories, components and their measurement. Physical activity, health and sports, 2, 54-63.

Ryan, R. (2000). Self-determination theory and the facilitation of intrinsic motivation, social development, and well-being. American Psychology, 55 (1), 68-78.

Serdiuk, L. Z. (2012). Psychology of motivation of future specialists' learning: system-synergetic approach: monograph. Kyiv: University "Ukraine".

Serdiuk, L. Z, Daniliuk, I. V, Turban, V. V, Penkova, O. I., Volodarskaya, N. D. et al. (2018). Psychological technologies of self-determination of personality development: monograph. Kyiv: G. S. Kostiuk Institute of Psychology of the NAES of Ukraine.

Serdiuk, L., Danyliuk, I. \& Chykhantsova, O. (2019). Psychological factors of secondary school graduates' hardiness. Social welfare: Interdisciplinary approach,9(1),93-103.DOI:10.21277/sw.v1i9.454

Virna, Zh. (2013). Axiology of quality of life of the personality. Personality psychology, 1 (4), 104-112.

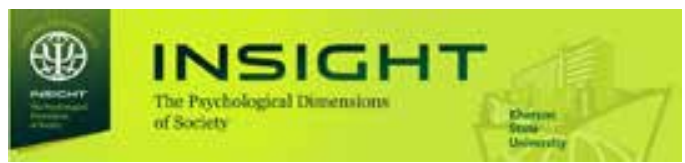

Baranauskienè, I., Serdiuk, L., Chykhantsova, O. (2016). Psychological characteristics of school-leavers' hardiness at their professional self-determination. Social welfare: Interdisciplinary approach, № 6 (2). P. 64-73. DOI: $10.21277 /$ sw.v2i6.275

Баженов С. А., Маликов Н. С. Качество жизни населения: теория и практика. Уровень жизни населения регионов России. 2002. № 2. С. 1-46.

Berenger V., Verdier-Chouchane A. (2007). Multidimensional Measures of Well-Being: Standard of Living and Quality of Life Across Countries. World Development, № 35 (7). Р. 1259-1276.

Чабан О.С. Якість життя пацієнта 3 позицій медичної психології. Мистецтво лікування. 2008. № 5 (51). С. 40-43.

Чиханцова О. Життєстійкість та іï зв'язок із цінностями особистості. Проблеми сучасної психології. 2018. № 42. С. 211-231. DOI: 10.32626/ 2227-6246.2018-42.211-231

Chykhantsova, 0 . The personal quality of life and life satisfaction. The $3_{r d}$ International scientific and practical conference. Scientific Congress (March 22-24, 2020) Barca Academy Publishing, Barcelona, Spain. 2020. P. 304-307.

Diener, E., Emmons, R., \& Larsen R. et al. (1985). The Satisfaction with Life Scale. Journal of Personality Assessment, 49, 71-75.

Галян І. Особистісні детермінанти відповідальності майбутніх педагогів. Науковий журнал Інсайт: психологічні виміри суспільства. 2019. № 1. C. 15-21. DOI: 10.32999/2663-970X/2019-1-2

Kaźmierczyk, J. Workforce segmentation model: banks' example. Entrepreneurship and Sustainability Issues. 2019. № 6 (4). P. 1938-1954. DOI: 10.9770/ jesi.2019.6.4(28)

Кокун О. М., Пішко І. О., Лозінська Н. С., Копаниця О. В., Малхазов О. Р. Збірник методик для діагностики психологічної готовності військовослужбовців військової служби за контрактом до діяльності у складі миротворчих підрозділів. Київ: НДЦ ГП ЗСУ, 2011. С. 142-144.

Леонтьев Д. А., Рассказова Е. И. Тест жизнестойкости. Москва: Смысл, 2006. 63 с.

Лібанова Е. М., Гладун О. М., Лісогор Л. С. та ін. Вимірюванняякостіжиття вУкраїні.Аналітична доповідь: монографія. Київ, 2013. 48 с.

Lyubomirsky, S., Lepper, H.S. (1999). A measure of subjective happiness: Preliminary reliability and construct validation. Social Indicators Research, № 46(2), P. 137-155. DOI: 10.1023/A:1006824100041

Приступа Є., Куриш Н. Якість життя людини: категорії, компоненти та їх вимірювання. Фізична активність, здоров'я і спорт. 2010. № 2. C. 54-63. 
Ryan, R. (2000). Self-detenrmination theory and the facilitation of intrinsic motivation, social development, and well-being. American Psychology. Vol. 55 (1). P. 68-78.

Сердюк Л. 3. Психологія мотивації учіння майбутніх фахівців: системно-синергетичний підхід: монографія. Київ: Університет “Україна", 2012. $323 \mathrm{c.}$

Сердюк Л. 3., Данилюк I. В., Турбан В. В., Пенькова О. І., Володарська Н. Д. та ін. Психологічні технології самодетермінації розвитку особистості: монографія / ред. Л. 3. Сердюк. Київ: Інститут психології імені Г.С. Костюка НАПН України, 2018. 192 с.

Serdiuk, L., Danyliuk, I., Chykhantsova, O. Psychological factors of secondary school graduates' hardiness. Social welfare: Interdisciplinary approach, 2019. № 9(1). P. 93-103. DOI: 10.21277/sw.v1i9.454

Вірна Ж. Аксіологія якості життя особистості. Психологія особистості. 2013. № 1(4). С. 104-112. 